\title{
ICHTHYOLOGY, BREEDING AND ECONOMIC IMPORTANCE OF RAINBOW TROUT IN POLAND
}

Department of Toxicology, Dairy Technology and Food Storage, West Pomeranian University of Technology in Szczecin, Poland

\begin{abstract}
One of the most well-known species of farmed fish in the world is rainbow trout (Oncorhynchus mykiss). In Poland, aside from rainbow trout, there are two more species: brook trout and brown trout, that have significantly lower importance. Adaptation features of rainbow trout, including high tolerance for varied nutrients and different environments, and low surface requirements, have allowed for effective breeding of this species. Breeding and husbandry takes place in ponds, which are adapted to size, quantity and the age of fish to ensure the best possible environmental conditions. Rainbow trout meat is a very good source of protein, vitamins, minerals, unsaturated fatty acids, essential amino acids. In distribution, rainbow trout occur in various forms, both fresh fish, gutted, fillets and smoked fish.
\end{abstract}

Key words: Oncorhynchus mykiss, breeding, ichthyology, industry.

\section{INTRODUCTION}

Rainbow trout are a freshwater fish, tolerant of a wide range of environments, breeding and feeding procedures. The rainbow trout (Oncorhynchus mykiss) create two main forms in the natural environment: it is migratory and sedentary. The form of a wanderer, known as the steelhead, spends the juvenile life in the river, and the period of feeding and rapid growth in the sea, and then returns to fresh waters in order to spawn. The form settled (shasta) spends the whole period of life in fresh waters (Goryczko 2005).

Trout is probably the most widespread fish species in the world. Since 1874, it has been introduced to waters on all continents except Antarctica, for breeding, recreational fishing and aquaculture (Maccrimmon 1972). The wide range of trout occurrence is the result of its good acclimatization features, such as rapid growth and tolerance to relatively high temperatures (Goryczko 2005). Rainbow trout were brought to Poland most likely in 1881-1889 and since then they have been farmed, and trout meat has become a valued product among consumers (Goryczko 2005). It is of great economic importance, also as an export product. It goes on sale fresh or as a frozen product, gutted or in the form of ready fillets or as a smoked product.

Corresponding author: Mariusz Szymczak, Technology and Processing of Aquatic Organisms Laboratory, Department of Toxicology, Dairy Technology and Food Storage, West Pomeranian University of Technology in Szczecin, Poland, Papieża Pawła VI 3, 71-450 Szczecin, e-mail: mariusz.szymczak@zut.edu.pl, ORCID: 0000-0003-3414-1963. 
Salmonid fish farming is now a rapidly developing field of fisheries, as evidenced by strong growth in the supply of rainbow trout, by more than 3\% compared to 2006 (Bontemps 2011). Trout is bought by $27.3 \%$ of Polish families, while $23.3 \%$ fresh and $12.8 \%$ smoked. Over $30 \%$ of consumers consider it to be a fish with pro-health properties (Kulikowski 2017). In the case of trout, breeding takes place in artificial or natural ponds, which are adapted to the needs of fish at each breeding stage.

\section{TROUT SPECIES}

Rainbow trout come from the rivers of America and North Asia that fall into the Pacific. In 1792, in Kamchatka, Asia, for the first time Walbuaum described the rainbow trout, calling it Oncorhynchus mykiss. More than 40 years later, in 1836, Richardson described trout from the Columbia River, in North America as Salmo gairdneri. In 1988, by decision of the American Fisheries Society, trout, as a species, was assigned to the Oncorhynchus family (Goryczko 2005). The name "trout" is a term for several species, originating from the salmonid family, differing in some biological features (Backiel 1964). In the $1930 \mathrm{~s}, 15$ species of rainbow trout were distinguished, based on differences in coloration, places of occurrence and body shape (Goryczko 2005). There are three species in Poland: the first one is settled brown trout, the second one is rainbow trout imported from North America, and the last one is source of trout (Sikorski 2014). The name "trout" is a term for several species, originating from the salmonid family, differing in some biological features (Backiel 1964). In the $1930 \mathrm{~s}, 15$ species of rainbow trout were distinguished, based on differences in coloration, areas and body shape (Goryczko 2005). There are three species in Poland: the first is settled brown trout, the other is rainbow trout imported from North America, and third source of trout (Sikorski 2014). They live in cold, relatively fast current streams or well-oxygenated upper sections of the river. All combine, however, they share a similar appearance, olive-brown ridges, golden sides with black spots and a silvery belly (Goryczko 2000). Despite similar features, all 3 species occurring in Poland differ in their economic application (Table 1).

Trout are predators, like the majority of salmonids (Brylinska 2000), in natural conditions they feed primarily on food of animal origin. They feed on animal seston, mainly gammarus (Frankiewicz et al. 1993) and vertebrates (Kara and Alp 2005). Another source of food are animals washed out from the banks, as well as small fish (Brylińska 2000). They are also cannibals, as there are cases where larger trouts eat the younger fish, but this phenomenon is relatively rare (Vik et al. 2001). In the breeding conditions, they are fed with fodder, being a mixture of animal and vegetable products. Feedstuff of animal origin are so-called wet fodder, most often meat, low-value fish or fresh slaughter waste (Guziur and Woźniak 2006). Despite this, works are underway to fish for trout, using only plant fodder (Dani 2006). 
Table 1. Trout species found in Poland

\begin{tabular}{llll}
\hline \multicolumn{1}{c}{ Type } & Natural occurrence & \multicolumn{1}{c}{ Domestication } & \multicolumn{1}{c}{ Economic importance } \\
\hline Brook trout & North America, spe- & Western North America, Asia, \\
(Salvelinus & cifically the north- & New Zealand, most of Europe & $\begin{array}{l}\text { Imported to Poland for fishing } \\
\text { fontinalis) }\end{array}$ \\
-eastern part of the & continent & $\begin{array}{l}\text { the upper Vistula section. Despite } \\
\text { multiple restocking, spontaneous } \\
\text { breeding exists only in the Eye of } \\
\text { the Sea. The economic impor- } \\
\text { tance is small }\end{array}$
\end{tabular}

\begin{tabular}{|c|c|c|c|}
\hline $\begin{array}{l}\text { Brown trout } \\
\text { (Salmo trutta } \\
\text { morpha fario) }\end{array}$ & $\begin{array}{l}\text { Almost all of Euro- } \\
\text { pe and North Africa } \\
\text { and a few in Asia }\end{array}$ & $\begin{array}{l}\text { From Spain throughout Europe } \\
\text { to the Urals, also Tasmania, } \\
\text { New Zealand, Argentina }\end{array}$ & $\begin{array}{l}\text { Was bred in ponds, but as the } \\
\text { rainbow trout was introduced into } \\
\text { the breeding pond, its importance } \\
\text { as a farmed fish was decreasing } \\
\text { and now it is mainly bred for } \\
\text { restocking pur-poses. It is very } \\
\text { attractive for anglers }\end{array}$ \\
\hline $\begin{array}{l}\text { Rainbow trout } \\
\text { (Oncorhynchus } \\
\text { mykiss) }\end{array}$ & $\begin{array}{l}\text { Western North Ame- } \\
\text { rica from the Kus- } \\
\text { kokwim River (Alas- } \\
\text { ka) to the Dei Pre- } \\
\text { sidio River Basin }\end{array}$ & $\begin{array}{l}\text { Occur on all continents except } \\
\text { Antarctica, and the range ex- } \\
\text { tends from the polar circle in the } \\
\text { north (Norway, Sweden, Alaska) } \\
\text { through the equator (Ecuador, } \\
\text { Kenya, Uganda) to Argentina }\end{array}$ & $\begin{array}{l}\text { Breeding in artificial and natural } \\
\text { reservoirs. Production in Poland } \\
\text { is mainly carried out in regions } \\
\text { on the foothills and in the north } \\
\text { in Varmia and Masuria and Po- } \\
\text { merania }\end{array}$ \\
\hline
\end{tabular}

Source: Brylińska (2000).

\section{TROUT ANATOMY}

Rainbow trout have a laterally constricted body. They have large, heavily toothed drench cavities. Their scales are cycloidal, small and similar to salmon scales. The tail is moderately indented, and in older fish it is almost straight. In relation to the total body length, their height is $23.3 \%$, head length $20.6 \%$ and body width $10 \%$ (Kalal 1972).

The heart is a muscular, two-chamber organ at the base of the throat and lies in the pericardial cavity, which is completely separated from the body cavity. The stomach is elongated, U-shaped, located between the esophagus and the intestine. In the anterior and middle part of the stomach of the trout, in the folds of the mucosa there are tubular glands producing hydrochloric acid and pepsin. Numerous mucus cells are present in the epithelium. The stomach has a pH of 1.5-4.0. The back of the stomach is defined by pyloric caeca that secretes enzymes. In rainbow trout, the number of pyloric caeca ranges from 27 to 80 (Szarek et al. 2013). The digestive process begins in the easily expandable stomach. The remaining part of digestion and absorption process takes place in the intestine, in the initial section are pyloric caeca, connecting directly to the intestinal lumen (Kilarski 2012).

The liver acts as an auxiliary digestive organ, securing bile through the bile duct. The kidney lies along the abdominal surface of the spine (Grodziński 1981). Trout have a single chamber swimbladder, responsible for maintaining the balance of the fish.

\section{REPRODUCTIVE CYCLE}

Trout reaches sexual maturity at the age of 2 to 5 years and is dependent on many factors, not only species, but also environmental factors such as water temperature, type of food, reservoir quality, growth rate or latitude (Bieniarczyk and Epler 1991). A typical mature rainbow trout can 
produce from 1.000 to 8.000 eggs in each season (Kilarski 2012). The reproduction process of rainbow trout together with techniques allowing its multiplication in culture is well known.

The most common method is to obtain eggs and incubate them. The most common approach is to obtain eggs and incubate them. The eggs are manually removed from the females (under anesthesia) by pressing the abdominal fins to the ventilation area or the air-spawning area, which causes the fish to be less loaded and produce lighter and healthier eggs. For fertilization, you need roe and milk, also sweet water, which is necessary for the movement, swelling of the eggs and hardening of the shells (Goryczko 2005).

In natural habitats, mainly on the western shores of North America, the breeding period for different forms of rainbow trout lasts from December to May, with most fish spawning in the spring. The optimum temperature for spawning of rainbow trout is within the range of $5.6-13.0^{\circ} \mathrm{C}$, up to $16.0^{\circ} \mathrm{C}$ (Szarek et al. 2013).

\section{BREEDING}

Breeding of fish and other aquatic species has been steadily growing for decades, and the breeding practices and related welfare issues are constantly evolving. They focus on legal standards and consumer requirements (EFSA 2009). One of the most important freshwater fish in Poland is rainbow trout. It tolerates a wide range of environmental and breeding conditions, which is a big advantage for breeders, allowing to avoid very high production costs. Basically, the whole market is dominated by one species - rainbow trout, while the remaining species are present in a very small amount. It is valued by breeders for the fast growth rate and resistance to relatively high water temperatures, high survivability and diverse breeding possibilities.

There are two main trout production systems in the European Union, the first one in fresh water and the second one is so-called sea production. Sea farming is almost identical to the production system of Atlantic salmon, where the larval and juvenile stages are bred in fresh water, then in later stages, they grow in seawater. The basic requirement for the production of these fish is a strong flow of cool (up to $20^{\circ} \mathrm{C}$ ), well oxygenated (over $6 \mathrm{mg} \cdot \mathrm{dm}^{-3}$ ) and first class purity water (Szarek et al. 2013). Trout are predators, so they need an efficient diet with a high protein content, because the digestive tract is adapted to the digestion of animal protein, and to a small extent to vegetable protein. In natural waters, it feeds on crustaceans and larvae of adult forms of water insects (Szarek et al. 2013).

In favorable environment, trout, after 10-12 months, reach a weight of $350 \mathrm{~g}$, and after 2 years weight of $3 \mathrm{~kg}$. There are also farms fattening trout at sea, where fish reside in floating cages, in medium saline waters of the Baltic Sea or in protected areas of the Scandinavian fjords. Good management of resources is important in fattening, which consists in faster growing trout from the herd. Typically, segregation is done 4 times during the production cycle. When trout reach commercial weight, they are caught from pools in grids or pumped alive if they were raised in cages. Ponds for breeding trout have small areas, depending on the species, adapted to the size of the fish placed in them (Table 2). 
Table 2. Types of ponds in trout farming

\begin{tabular}{|c|c|c|c|}
\hline Type & Structure & Size & Application \\
\hline $\begin{array}{l}\text { Hatching } \\
\text { tank }\end{array}$ & $\begin{array}{l}\text { Trough or rotating } \\
\text { tank }\end{array}$ & $\begin{array}{l}\text { The area does not exceed } 20 \mathrm{~m}^{2} \text {. Depth of } 40 \\
\mathrm{~cm} \text {. Maximum density } 30 \mathrm{~kg} \cdot \mathrm{m}^{-3}\end{array}$ & For hatching \\
\hline $\begin{array}{l}\text { Nursery } \\
\text { pond }\end{array}$ & $\begin{array}{l}\text { Concrete troughs } \\
\text { and concrete or } \\
\text { earth ponds, pre- } \\
\text { ferably of the trench } \\
\text { or rotary type }\end{array}$ & $\begin{array}{l}\text { The area depends on the type of construction, } \\
\text { the concrete channel does not exceed } 20 \mathrm{~m}^{2} \text {, } \\
\text { for a concrete or ground pond below } 100 \mathrm{~m}^{2} \\
\text { Maximum density } 50 \mathrm{~kg} \cdot \mathrm{m}^{-3} \\
\text { The amount of water required for } 1 \mathrm{~kg} \text { depends } \\
\text { on the weight of the trout, the temperature and } \\
\text { the frequency of water exchange }\end{array}$ & $\begin{array}{l}\text { For trout in the first year of } \\
\text { life. Usually up to a weight } \\
\text { of } 0.5-60 \mathrm{~g} \text { per pc. If oxy- } \\
\text { genation is used, it is pos- } \\
\text { sible to raise hatch and pro- } \\
\text { duce fry. Fish must be se- } \\
\text { lected for body weight, health } \\
\text { (no internal and external pa- } \\
\text { rasites) and proper nutrition }\end{array}$ \\
\hline $\begin{array}{l}\text { Fattening } \\
\text { pond }\end{array}$ & $\begin{array}{l}\text { The most popular } \\
\text { are so-called ditch } \\
\text { ponds, with the } \\
\text { inflow and outflow } \\
\text { of water in the } \\
\text { entire width }\end{array}$ & $\begin{array}{l}\text { These rectangular ponds, usually made of } \\
\text { concrete, use two techniques: continuous flow } \\
\text { - an open system consisting in that water from } \\
\text { the river flows through the installation through } \\
\text { the channel, and recirculation - a closed } \\
\text { system where water circulates between tanks, } \\
\text { and it is then recycled for re-use. Such ponds } \\
\text { are built in "batteries", that is, } 3 \text {, one after the } \\
\text { other. This allows better use of water. In good } \\
\text { conditions, i.e. at a suitable temperature } \\
\text { of approx. } 15^{\circ} \mathrm{C} \text {, a compaction of approx. } \\
80 \mathrm{~kg} \cdot \mathrm{m}^{-3} \text { can be achieved }\end{array}$ & $\begin{array}{l}\text { Most often, the fry are } \\
\text { transferred to the fattening } \\
\text { ponds in early spring }\end{array}$ \\
\hline $\begin{array}{l}\text { Spawning } \\
\text { tank }\end{array}$ & $\begin{array}{l}\text { It should resem- } \\
\text { ble a natural river } \\
\text { bed, ideally it would } \\
\text { be a pond with na- } \\
\text { tural ground }\end{array}$ & $\begin{array}{l}\text { Water speed should not be less than } 0.3 \mathrm{~m} \cdot \mathrm{s}^{-1} \text {, } \\
\text { and well oxygenated. It is advisable to maintain } \\
\text { low densities, no more than } 10 \mathrm{~kg} \cdot \mathrm{m}^{-3} \text {. The } \\
\text { ideal solution is to provide a constant water } \\
\text { temperature }\left(12^{\circ} \mathrm{C}\right) \text { minimum six months before } \\
\text { spawning. Ponds with natural substrate are } \\
\text { more efficient than those made of concrete or } \\
\text { plastic }\end{array}$ & $\begin{array}{l}\text { For trout preparing for spaw- } \\
\text { ning. The date of spawning } \\
\text { depends on temperature, } \\
\text { water current and light. Fish } \\
\text { usually have between } 3 \text { and } \\
5 \text { years, and the sex ratio is } \\
1 \text { male to } 5-10 \text { females }\end{array}$ \\
\hline
\end{tabular}

Source: Goryczko (2005), Guziur and Woźniak (2006).

\section{AQUACULTURE OF TROUT IN POLAND}

Aquaculture in Poland is included in the inland fishery sector. In about 200 farms, there is rearing and breeding of freshwater fish, mainly carp and trout (Mard 2014). In 2015, thanks to aquaculture, 37.0 thousand tons of fish were acquired in Poland, which is less by $7.8 \%$ than in 2014 and by $2.5 \%$ less than in 2005 (FAO 2016). In the years 2006-2010 a decrease in rainbow trout farming was observed, however since 2010 there has been a dynamic development (Fig. 1).

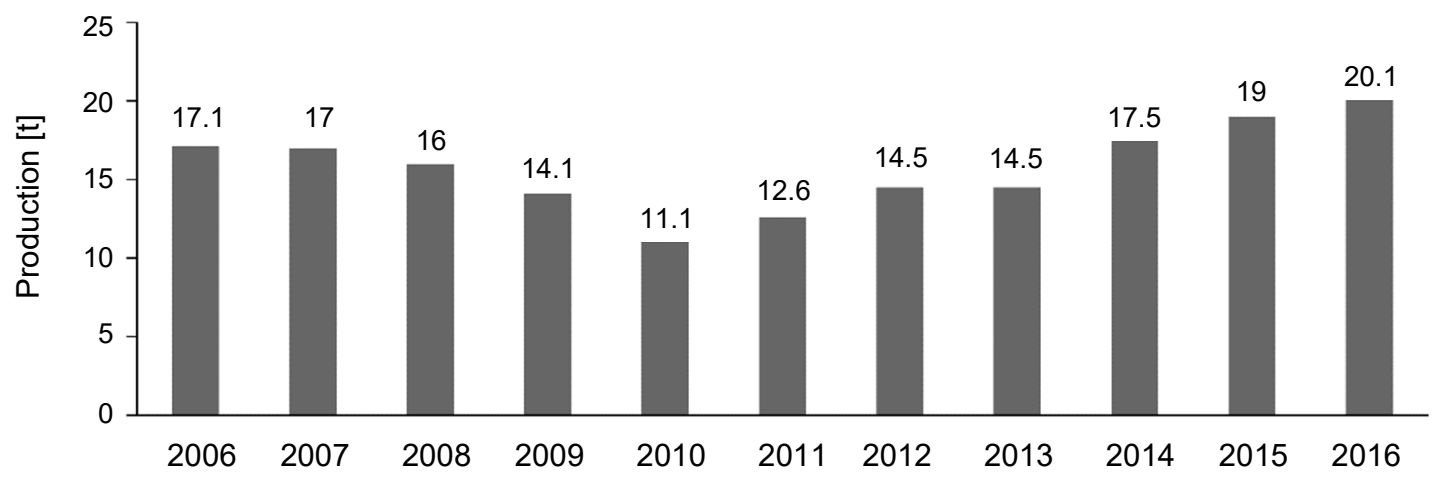

Fig. 1. Production of rainbow trout in Poland in 2007-2016

Source: FEAP (2017). 
The majority of fish produced by Polish aquaculture supply the domestic market. The main fish for export is rainbow trout: 17-24\% of domestic production goes mainly to Germany. Almost all trout destined for export are processed (Table 3).

Table 3. Types of rainbow trout products and their mass (tonnes) intended for export in 2012-2016

\begin{tabular}{lrrrrr}
\hline $\begin{array}{c}\text { Exported } \\
\text { product }\end{array}$ & 2012 & 2013 & 2014 & 2015 & 2016 \\
\hline Alive & 590 & 709 & 462 & 582 & 932 \\
\hline Fresh & 143 & 435 & 1025 & 1022 & 1162 \\
\hline Frozen & 176 & 122 & 88 & 87 & 221 \\
\hline Fresh fillet & 232 & 352 & 192 & 501 & 669 \\
\hline Frozen fillet & 202 & 203 & 513 & 407 & 600 \\
\hline Smoked & 3043 & 3634 & 4346 & 3929 & 3292 \\
\hline Sum & 4386 & 5455 & 6626 & 6528 & 6876 \\
\hline
\end{tabular}

Source: Eumofa (2017).

\section{THE NUTRITIONAL VALUE OF TROUT MEAT}

In a properly balanced human diet, fish and their preserves play an important role. Trout meat is a source of valuable and highly digestible protein, phospholipids and unsaturated fatty acids, but also vitamins and minerals (Fig. 2).

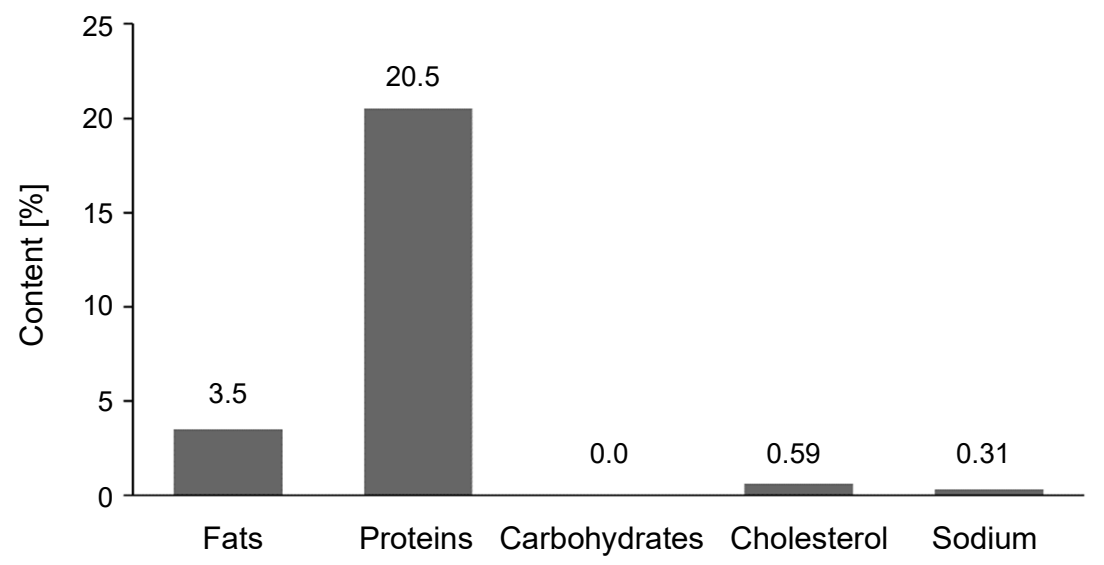

Fig. 2. Nutrient content in $100 \mathrm{~g}$ rainbow trout meat Source: USDA (2017).

Rainbow trout meat is characterized by high protein content from 18.72 to $19.74 \%$ and low fat content from 3.63 to $7.40 \%$ (Tkaczewska and Migdał 2012). Analyzing the basic ingredients of fish meat, the largest variability of quantitative and qualitative are shown by lipids. Their concentration depends on the age and sex of the fish, temperature, climate, and the type and availability of food, or fishery pollution (Guler et al. 2008).

The nutritional value of the protein depends on the amino acid composition. The total content of exogenous and relatively exogenous amino acids in fish usually exceeds that calculated for the reference protein, i.e. $26.5 \mathrm{~g}$ in $100 \mathrm{~g}$ of protein. The rainbow trout protein 
is characterized by a particularly high content of asparagine, glutamine and lysine, leucine, aromatic amino acids (phenylalanine and tyrosine), sulfur amino acids (methionine and cysteine and histidine) (Table 4).

Table 4. Average content of amino acids in $100 \mathrm{~g}$ of fresh rainbow trout meat

\begin{tabular}{lc}
\hline \multicolumn{1}{c}{ Amino acid } & Content [g] \\
\hline Alanine & 1.239 \\
\hline Arginine & 1.225 \\
\hline Asparagine & 2.097 \\
\hline Cysteine & 0.220 \\
\hline Glutamine & 3.057 \\
\hline Glycine & 0.983 \\
\hline Histidine & 0.603 \\
\hline Isoleucine & 0.944 \\
\hline leucine & 1.664 \\
\hline Lysine & 1.881 \\
\hline Methionine & 0.606 \\
\hline Phenylalanine & 0.799 \\
\hline Proline & 0.724 \\
\hline Serine & 0.836 \\
\hline Threonine & 0.898 \\
\hline Tryptophan & 0.229 \\
\hline Tyrosine & 0.691 \\
\hline Valine & 1.055 \\
\hline
\end{tabular}

Source: USDA Nutrient Database (2017).

Consuming rainbow trout provides a large dose of vitamins - including vitamins $A, C$ and $B$ vitamins. It is also a good source of minerals - phosphorus, potassium, magnesium, calcium, iron, and microelements such as: zinc, copper, manganese (Table 5).

Table 5. The content of vitamins and minerals in $100 \mathrm{~g}$ of fresh rainbow trout meat

\begin{tabular}{lc}
\hline \multicolumn{1}{c}{ Vitamins and minerals } & Content \\
\hline Vitamin A & $19 \mu \mathrm{g}$ \\
\hline Vitamin B6 & $0.4 \mathrm{mg}$ \\
\hline Vitamin B12 & $4.5 \mu \mathrm{g}$ \\
\hline Vitamin C & $2.4 \mathrm{mg}$ \\
\hline Calcium & $67 \mathrm{mg}$ \\
\hline Iron & $0.7 \mathrm{mg}$ \\
\hline Magnesium & $31 \mathrm{mg}$ \\
\hline Phosphorus & $271 \mathrm{mg}$ \\
\hline Zinc & $1.1 \mathrm{mg}$ \\
\hline Copper & $0.1 \mathrm{mg}$ \\
\hline Manganese & $0.2 \mathrm{mg}$ \\
\hline Selenium & $12.6 \mu \mathrm{gg}$ \\
\hline Retinol & $19 \mu \mathrm{g}$ \\
\hline Vitamin B1 & $0.1 \mathrm{mg}$ \\
\hline Folic acid & $0.1 \mathrm{mg}$ \\
\hline Vitamin B3 & $5.4 \mathrm{mg}$ \\
\hline
\end{tabular}

Source: USDA Nutrient Database (2017). 
Fatty acids are components of many other compounds with biological activity, including tissue hormones (prostaglandins), neurotransmitters (serotonin and dopamine), eicosanoids with anti-inflammatory and antithrombotic effects (Szarek et al. 2013). Information on the beneficial effects on the physical and mental state resulting from the consumption of fish appears systematically in the literature. Omega-3 fatty acids have a positive effect on the condition of the cardiovascular system, and more specifically on reducing the number of sudden cardiac deaths (Szarek et al. 2013). The rainbow trout meat contains a relatively large amount of omega-3 fatty acids, $0.7 \mathrm{~g}$ in $100 \mathrm{~g}$ fresh fish (Table 6). The amount of omega-3 fatty acids is proportional to the amount of adipose tissue in fish, so it is also dependent on the season of the catch and the species of fish.

Table 6. Fatty acid content in $100 \mathrm{~g}$ of fresh rainbow trout

\begin{tabular}{lc}
\hline \multicolumn{1}{c}{ Fatty acids } & Content $[\mathrm{g}]$ \\
\hline Docosahexaenoic acid (DHA) & 0.4 \\
\hline Eicosapentanoic acid (EPA) & 0.2 \\
\hline Docosapentaene acid (DPA) & 0.1 \\
\hline Total amount of Omega-3 fatty acids & 0.7 \\
\hline
\end{tabular}

Source: USDA (2017).

\section{SAFETY AND QUALITY OF TROUT PRODUCTS}

The rules and requirements for fish intended for breeding or intended for sale are regulated in Poland by two industry standards BN-76 / 9147-06 and PrPN-R-93101 and the Act of 11 March 2004 on the protection of animal health and combating infectious animal diseases (Ustawa z dnia 11 marca 2004 r. o ochronie zwierząt oraz zwalczaniu chorób zakaźnych zwierząt). However, determining the quality of fish breeding and slaughter are the recommendations of the European Food Safety Authority EFSA Food Safety Authority (EFSA 2005).

According to EFSA expert opinions, there are no significant differences between wild and farmed fish, both in terms of safety and nutritional value. When assessing the risk of eating fish, the Scientific Panel on contaminants in the food chain focused on the main fish species on the European Union market: herring, salmon, tuna, rainbow trout, carp, anchovy, mackerel and anchovy. The value of the risk assessment of the level of contamination of fish meat is significantly affected by the season, breeding location and types of feed (EFSA 2005).

Fish that are intended for sale are subjected to treatment in order to preserve the freshness of meat for as long as possible. The feeding method is changed and the feed is limited before the slaughter itself. Feeding until the end of slaughter causes too much percentage of bowel in the entire fish and high enzymatic activity of the digestive tract. Trout is a predatory fish whose digestive juices adversely affect the meat, contributing to a faster deterioration of the quality of muscle tissue, causing it to relax (Ciereszko and Ocalewicz 2007). In addition to the appropriate calorific value of standard feed, about $4.000 \mathrm{kcal}$, not less than $10 \%$ of the production cycle time, fodder with pigment are used to color the meat of larger fish (Goryczko 2005). Dyeing aims to achieve the salmon color of the muscle desired by consumers (Towers 2010). In addition to the appropriate coloration, before the sale, fish is evaluated primarily 
by the appearance of the eyes, which cannot be turbid, sunken or staring and fish-shaped. There also cannot be any deformation of the body, as well as a large loss of scales or damage to the fins (Goryczko 2005).

Fish gutting should be done as soon as possible after being caught in order to effectively guarantee quality and safety (Goryczko 2005). The pre-treatment to which the trout is subjected is: gutting, heading, portioning, filleting, skinning, production or sale of fried, smoked and grilled fish. The type of processing depends on the size of the fish, its condition or the absence of external damage.

\section{PROCESSING}

The breeding of rainbow trout does not end with fishing and subsequent sale in the food or retail industry. It also covers the sale of live fish for stocking rivers and lakes for recreational purposes or for fisheries being a tourist attraction. Also eggs and individuals of childbearing age are sold to other farms. On the other hand waste from trout processing is also used for the production of fish meal or as a fertilizer (Towers 2010).

A popular product among consumers is fresh, gutted fish left with the a head. The meat of this fish has a colour from white to pink, with a characteristic delicate taste. Meat-coloured preferences vary widely around the world, white meat is preferred in the US and pink in Europe and other parts of the world (Towers 2010). Trout intended for consumption usually weigh between $280-400 \mathrm{~g}$ and reach this value after 12-18 months. The desired size of the fish depends on the taste of consumers, different in different regions of the world. In the United States, it is 450-600 g, while in Canada, Chile, Norway, Sweden and Finland, it is 3-5 kg (Towers 2010). Rainbow trout is treated by consumers as a substitute for salmon, but its price is underestimated in relation to the latter (Kulikowski 2017).

The rainbow trout farming in Poland is one of the most appreciated in the world. Historically, the largest suppliers in the European Union were Denmark, France, Germany, Italy and Spain. These countries, however, recorded a decline in production, while Poland with 18 thousand tonnes of portioned trout produced in 2016, took 5th place. The portioned fish has a size of $250-400 \mathrm{~g}$ and is one of the most frequently purchased by consumers. Larger trouts are rarely raised in Poland, mainly for reproductive purposes (Eumofa 2017).

\section{CONCLUSION}

Rainbow trout is a fish whose breeding and economic importance is constantly growing. It is possible thanks to the relatively simple breeding method, which does not require large financial and surface expenditure. Another advantage is the high acclimatization of these fish, high survival rate and their mass growth rate. The availability of fresh water and low environmental requirements allow for continuous expansion of the breeding industry. The farm uses different types of fodder: wet or in the form of granules or innovative nutrition only with the aid of plant fodder. Rainbow trout meat is a good source of fat, protein and a source of vitamins and amino acids. Dishes prepared from it are low in calories. The market comes in a variety of forms, adapted to the growing requirements of consumers. It is also an excellent export product valued in the European Union. 


\section{REFERENCES}

Backiel T. 1964. Pstrągi. Warszawa, PWRiL. [in Polish]

Bieniarczyk K., Epler P. 1991. Rozród ryb. Kraków, Lettra. [in Polish]

Bontemps S. 2008. Analiza produkcji i sprzedaży pstrągów tęczowych w 2007 r. [Analysis of production and sale of rainbow trout in 2007]. Kom. Ryb. 4, 25-36. [in Polish]

Bontemps S. 2011. Analiza produkcji i sprzedaży pstrągów [Analysis of production and sale of rainbow trout]. Prz. Ryb. 5, 20-22. [in Polish]

Brylińska M. 2000. Ryby słodkowodne Polski. Warszawa, PWN, 521. [in Polish]

Callet T., Médale F., Larroquet L., Surget A., Aguirre, P., Kerneis T., Labbé L., Quillet E., Geurden I., Skiba-Cassy S., Dupont-Nivet M. 2017. Successful selection of rainbow trout (Oncorhynchus mykiss) on their ability to grow with a diet completely devoid of fishmeal and fish oil, and correlated changes in nutritional traits. Plos One 12, e0186705.

Ciereszko A., Ocalewicz K. 2007. Modern methods for rainbow trout production. A time for trout. Focus Fish Breed. Academia 1, 20-23.

Dani D. 2018. A review on replacing fish meal in aqua feeds using plant protein sources. Inter. J. Fish. Aquatic Stud. 6, 164-179.

EFSA. 2005. Provides advice on the safety and nutritional contribution of wild and farmed fish, https://www.efsa.europa.eu/en/press/news/050704, access: 4.02.2018.

EFSA. 2009. Animal welfare aspects of husbandry systems for farmed trout. Scientific Opinion of the Panel on Animal Health and Welfare, https://www.efsa.europa.eu/en/efsajournal/pub/796, access: 04.02.2018.

Eumofa. 2017. Fresh portion trout in Poland, https://www.eumofa.eu/documents/20178/76127/ fresh+trout+in+Poland/d9af17a3-0156-41b0-9aae-b66fdc0fdef7, access: 4.02.2018.

FAO. 2016. The State of World Fisheries and Aquaculture. Contributing to food security and nutrition for all. Rome, [b.w.], 200, https://www.fao.org/3/a-i5555e.pdf, access: 16.10.2019.

FEAP. 2017. Production report 2017 covering European fish farming from 2008-2016.

Frankiewicz P., Zalewski M., Thorpe J. E.. 1993. Feeding pattern of brown trout (Salmo trutta L.) from the River Earn (Scotland), in relation to invertebrate drift. Pol. Arch. Hydrobiol. 40, 15-29.

Goryczko K. 2000. Pstrąg tęczowy Oncorhynchus mykiss Walbaum, 1792, w: Ryby słodkowodne. Red. M. Brylińska. Warszawa, PWN. [in Polish]

Goryczko K. 2005. Pstrąg: chów i hodowla, poradnik hodowcy. Olsztyn, IRS. [in Polish]

Grodzinski Z. 1981. Anatomia i embriologia ryb. Warszawa, PWRiL. [in Polish]

Guler G.O., Kiztanir B., Aktumsek A., Citil O.B., Ozparlak H. 2008. Determination of the seasonal changes on total fatty acid composition and $\omega 3 / \omega 6$ rations of carp (Cyprinus carpio L.) muscle lipids in Beysehir Lake (Turkey). Food Chem.108, 689-694.

Guziur J., Woźniak M. 2006. Produkcja ryb w małych zbiornikach. Warszawa, Hoża Oficyna Wydawnicza. [in Polish]

Kalal L. 1972. Linearni znaky u pstruha duhoveho - Salmo gairdnerii. Praha, Sb. VŠZB, 202-226. [in Czech/Slovak]

Kara C., Alp A. 2005. Feeding habits and diet composition of brown trout (Salmo trutta) in the upper streams of River Ceyhan and River Euphrates in Turkey. Turk. J. Vet. Anim. Sci. 9, 417-428.

Kilarski W. 2006. Anatomia ryb. Poznań, PWRiL. [in Polish]

Kulikowski T. 2017. Rynek ryb słodkowodnych w Polsce, czyli wnioski z XLII Konferencji Hodowców Ryb Łososiowatych [Freshwater fish market in Poland, conclusions from the XLII Conference of Fish Breeders]. Mag. Przem. Ryb. 5, 40. [in Polish]

Maccrimmon R. 1972. World distribution of rainbow trout (Salmo gairdneri): Further observations. J. Fish. Res. Board Canada 29, 1788-1791.

MARD. 2014. Concept in the National Strategy for the Development of Fisheries in 2007-2013. Warszawa, Ministry of Regional Development. 
Sikorski Z.E. 2004. Ryby i bezkręgowce morskie. Warszawa, WNT. [in Polish]

Szarek J., Skibniewska K.A., Zakrzewski J., Guziur J. 2013. Jakość pstrąga tęczowego (Oncorhynchus mykiss, Walbaum 1792) z technologii stosowanych w Polsce, w: Testowanie technologii produkcji pstrąga stosowanych w Polsce w świetle Rozporządzenia Komisji (WE). nr 710/2009. Olsztyn, ElSet. [in Polish]

Tkaczewska J., Migdał W. 2012. Porównanie wydajności rzeźnej, zawartości podstawowych składników odżywczych oraz poziomu metali ciężkich w mięśniach pstrąga tęczowego (Oncorhynchus Mykiss) pochodzącego z różnych rejonów Polski [Comparison of slaughtering efficiency, content of basic nutrients and level of heavy metals in rainbow trout muscle (Oncorhynchus Mykiss) from different regions of Poland]. Żywn. Nauka Technol. Jakość 5, 177-186. [in Polish]

Towers L. 2010. How to farm rainbow trout. The fish site, https://thefishsite.com/articles/culturedaquaculture-species-rainbow-trout, access: 16.01.2018.

USDA Nutrient Database. 2017. Statistics Report: 15240. Fish, trout, rainbow, farmed, raw. https://ndb.nal.usda.gov/ndb/foods/show/4718?n1=\%7Bn1\%3D\%7BQv\%3D1\%7D\%2C+Qv\%3D1 $\% 7 D \& f g c d=\&$ man $=\& l f a c e t=\&$ count $=\& \max =50 \&$ sort=ndb\&qlookup $=\&$ offset=0\&format $=$ Stats \&new $=\&$ measureby $=\& d s=\& q t=\& q p=\& q a=\& q n=\& q=\& i n g$, access: 3.03 .2018 .

Ustawa z dnia 11 marca 2004 r. o ochronie zwierząt oraz zwalczaniu chorób zakaźnych zwierząt. DzU z 2004 r., nr 69, poz. 625. [in Polish]

Vik J. O., Borgstrøm R., Skaala Ø. 2001. Cannibalism governing mortality of juvenile brown trout, Salmo trutta, in a regulated stream. Regul. Rivers Res. Mgmt. 17, 583-594.

\title{
ICHTIOLOGIA, HODOWLA I ZNACZENIE GOSPODARCZE PSTRĄGA TĘCZOWEGO W POLSCE
}

\begin{abstract}
Streszczenie. Jednym z bardziej znanych gatunków ryb hodowlanych na świecie jest pstrąg tęczowy (Oncorhynchus mykiss). W Polsce oprócz pstrąga tęczowego występują jeszcze dwa gatunki: pstrąg źródlany oraz potokowy, które mają istotnie mniejsze znaczenie. Cechy przystosowawcze pstrąga tęczowego, w tym wysoka tolerancja, dotycząca zarówno zróżnicowanych składników pokarmowych, jak i różnych środowisk, oraz małe wymagania powierzchniowe pozwoliły na efektywną hodowlę tego gatunku. Chów i hodowla odbywają się w stawach, które są dostosowane do wielkości, ilości oraz wieku ryb, aby zapewnić im możliwie najlepsze warunki środowiskowe. Mięso pstrąga tęczowego stanowi bardzo dobre źródło białka, witamin, składników mineralnych, nienasyconych kwasów tłuszczowych, aminokwasów egzogennych. Pstrąg tęczowy w dystrybucji występuje pod różnymi postaciami - zarówno w postaci świeżych ryb, patroszonych, jak i filetów oraz przetworów wędzonych, w żelatynie i w konserwach.
\end{abstract}

Słowa kluczowe: Oncorhynchus mykiss, hodowla, ichtiologia, przemysł. 
